\title{
Skinning Antenatal Care Accuracy To Maternal Complication At Dr. H. Moch Ansari Saleh Hospital Banjarmasin
}

\author{
Fakhruddin Razy ${ }^{1}$ \\ ${ }^{1}$ Department of Science Midwifery, STIKES Sari Mulia, Banjarmasin Indonesia \\ *razyzabi123@gmail.com \\ Anggrita Sari ${ }^{2}$ \\ ${ }^{2}$ Academy of Midwifery Sari Mulia, Banjarmasin Indonesia \\ anggrita_sari@akbidsarimulia.ac.id \\ Rizka Amalia ${ }^{1}$ \\ ${ }^{1}$ Department of Science Midwifery, STIKES Sari Mulia, Banjarmasin Indonesia \\ Rizka_amalia@gmail.com
}

\begin{abstract}
Objective : To analize skrinning antenatal care accuracy to intranatal complication at Dr. H. Moch Ansari Saleh Hospital Banjarmasin.

Method: The research used analytical survey with cross-sectional approach.Population and sample were all postpartum mothers who have KIA book at Dr. H. Moch Ansari Hospital Banjarmasin on March 11-18 2017, amount, 80 people, by using total sampling technique. The data was analyzed by Chi-Square test with $95 \%$ trust level.

Result: a Postpartum mother who experiences intranatal complication compatible to the score during pregnancy was 67 people $(91,8 \%)$. There was relationship between risk prediction of pregnancy according to poedjirochjati score and the case intranasal complication at Dr. H. Moch Ansari Saleh Hospital Banjarmasin $(\mathrm{p}=0,000<\alpha=0,05)$

Conclusion: Pregnancy mother who had a high score of poedjirochjati experienced intranatal complication more than the mother who has a lower score of poedjirochjati. Increasing antenatal care checking can be detected early stage complication.

Key word: Screening antenatal care accuracy, intranatal complication.
\end{abstract}

\section{INTRODUCTION}

Complications of pregnancy, labor, and postpartum are health problems that cause maternal mortality to be higher. According to WHO MMR in 2013, it reaches 210 per 100,000 live births caused by bleeding, hypertension, infections, and indirect causes. IMR in the world reached 34 per 1,000 live births, while the world's Neonatal Death Rate reached 20 per 1,000 live births [1]

In Indonesia by 2012 IDHS, Maternal Mortality Rate (MMR) increased to 359 deaths per 100,000 live births and Infant Mortality Rate (IMR) of 32 per 1,000 live births, this has not achieved what SDG's target has been targeted to reduce MMR 70 
per 100,000 KH, decreasing IMR by 12 per $1000 \mathrm{KH}[1]$

The number of high-risk pregnant women/complications in the province of South Kalimantan in 2014 as many as 1131 pregnant women from 12902 people at 26 Puskesmas in Banjarmasin. Data from the Health Office Banjarmasin City of AKI mostly is due to complication of pregnancy, childbirth, and postpartum that is preeclampsia/eclampsia and bleeding. The incidents most happened to high-risk pregnant mother such as too young, too old, and too close to pregnancy distance in working area of Puskesmas Pekauman

Because of the higher MMR, government to make various efforts, namely integrated antenatal care program to $\mathrm{p}$ midwives in the villages, family and community empowerment using KIA book and program $(\mathrm{P} 4 \mathrm{~K})$ In addition, the role of midwives to reduce MMR is by screening the poedji rochjati score card used as a familybased antenatal screening tool with a risk approach to detect early risk factors and pregnancy complications so that pregnant women can be directed to secure birth planning by referring the right and planned [2]

Based on the data from Dr. H. Moch. Ansari Saleh Hospital, MMR in 2015 as much as $8 / 100.000 \mathrm{KH}$, while the IMR as much 136 / 1,000 KH. A number of mothers with complications in RSUD Dr. H. Moch. Ansari Saleh from referrals and non-referrals in 2015 decreased 801 from 4,776 deliveries, while in 2016 there was 1,485 births complication from 3,845 labor. The high complication of labor was caused by preeclampsia, infection/complication, and postpartum hemorrhage [3].

Based on the above facts, the researcher wants to contribute to increase the target of SDGs and decrease the MMR and IMR that was through the research done by analyzing the accuracy of Antenatal Care Screening on Complications of Birth at Dr. H. Moch. Ansari Saleh Hospital Banjarmasin.

\section{METHOD AND PROCEDURES}

The research was observational analytic research with a cross-sectional design with a quantitative approach that observed variables, measured at the same time at the time of the research. The population in this study were all postpartum mothers with KIA books. On 1118 March 2017 was 80 people. The Sampling was using the total random sampling so that the entire population of the sample.

The independent variable influences or causes the emergence of the dependent variable. Independent variable in this research was accurate prediction score poedji rochjati, while the dependent variable in this research was complication labor. Data collection done by is using quantitative data types and data sources used were primary data obtained from the data of field research results by conducting data filling through observation 
and with aids used in the form of checklist score card poedji rochjati.

Researchers analyzed the accuracy between one variable and another variable that was the correlation between predictive score poedji rochjati and the complication labor at Dr. H. Moch. Ansari Saleh Hospital Banjarmasin. Univariate data analysis technique was done by the process of data compilation; editing, coding, scoring, and tabulating then classifying, processing by using the simple statistical technique to see quantitative data that is measuring the distribution of prediction relationship score poedji rochjati to the complication of delivery.

Bivariate analysis of the study using statistical test analysis with Chi-Square test to determine the accuracy of the prediction score poedji rochjati against complications of labor. The test was used to measure the relationship between two variables that were meaningful or meaningless. The significance test was done using $\mathrm{a}=0.05$ then confident interval $95 \%$. Statistical test results if the value of $p$ $<0.05$ then there is a significant relationship between the prediction of pregnancy risk according to the score poedji rochjati with the incidence of complications of childbirth

\section{RESULTS}

Score Poedji Rochjati

Fetuses who categorized as low-risk pregnancies were 9 people $(11 \%)$, high-risk pregnancies were 50 people $(63 \%)$ and very high-risk pregnancies were 21 people (26\%).
Table 1. Pregnancy Risk in Postpartum Mother

\begin{tabular}{llcc}
\hline \multirow{2}{*}{ No } & Risk of Pregnancy & Amount & $\%$ \\
\hline 1 & Pregnancy Low Risk & 9 & $11 \%$ \\
2 & High-Risk Pregnancy & 50 & $63 \%$ \\
3 & Very High-Risk Pregnancy & 21 & $26 \%$ \\
& Total & 80 & $100 \%$ \\
\hline
\end{tabular}

Source: Primary Data

\section{Labor}

It was observed that out of 80 samples, postpartum women experiencing labor complications were 70 people $(87.5 \%)$ and postpartum women who did not have labor complications amounted to 10 people $(12.5 \%)$.

Table 2. Distribution of Labor Complications in Postpartum Mothers

\begin{tabular}{lccc}
\hline No & Maternity Condition & Total & $\%$ \\
\hline 1 & Complications & 70 & $87.5 \%$ \\
2 & No Complications & 10 & $12.5 \%$ \\
& Total & 80 & $100 \%$ \\
\hline
\end{tabular}

Source: Primary Data

Prediction Score Poedji Rochjati

The number of postpartum mothers who have the accuracy of score poedji rochajti with the incidence of labor complications as much as 73 postpartum (91\%), and postpartum mothers who do not exactly experience complications of birth in accordance with the score poedji rochjati who had during pregnancy as many as 7 people postpartum $(9 \%)$. 
Table 3. Distribution of Precision Prediction Score Poedji Rochjati of Postpartum Mother

\begin{tabular}{lccr} 
No & Prediction & Amount & $\%$ \\
\hline 1 & Exactly & 73 & $91 \%$ \\
2 & Not Exact & 7 & $9 \%$ \\
& Total & 80 & $100 \%$ \\
\hline
\end{tabular}

Source: Primary Data

\section{Accuracy of Labor Complications}

The number of postpartum mothers belonging to low-risk pregnancies did not suffer from complications of $6(7.5 \%)$, postpartum mothers belonging to high-risk pregnancies suffered the exact labor complication as much as 46 people $(57.5 \%)$ and postpartum which was classified as pregnancy risk very high right complicated during childbirth as many as 21 people $(26.3 \%)$.

Table 4. Distribution of Complications of Maternity Complications in Postpartum Mothers

\begin{tabular}{clrc}
\hline No & Accuracy of Complications of Labor & \multicolumn{2}{c}{ Amount \% } \\
\hline 1 & KRR Precise No Complication & 6 & $7.5 \%$ \\
2 & KRR Not Exactly Complicated & 3 & $3.7 \%$ \\
3 & Correct Kid Suffer Complications & 46 & $57.5 \%$ \\
4 & Inappropriate KRT Not Complicated & 4 & $5 \%$ \\
5 & KRST Exactly Complicated & 21 & $26.3 \%$ \\
6 & Correct KRST Not Complicated & 0 & $0 \%$ \\
& Total & 80 & $100 \%$ \\
\hline
\end{tabular}

Source: Primary Data

The bivariate analysis on the table 4.5 showed that postpartum women categorized as high and very high-risk pregnancies were 14 times more likely to experience labor complications than postpartum women who were categorized as low-risk pregnancies at the time of pregnancy and there was a risk prediction between pregnancy according to the score poedji rochjati and the occurrence of labor complication at Dr. H. Moch. Ansari Saleh Hospital Banjarmasin.

Table 5. Prediction Distribution Prediction Score Poedji

Rochjati Against Complications Birth

\begin{tabular}{|c|c|c|c|c|c|c|c|c|}
\hline \multirow{2}{*}{$\begin{array}{l}\mathrm{N} \\
\mathrm{O}\end{array}$} & \multirow{2}{*}{$\begin{array}{l}\text { Maternity } \\
\text { Condition }\end{array}$} & \multicolumn{4}{|c|}{$\begin{array}{l}\text { Precision Prediction } \\
\text { Score Poedji Rochjati }\end{array}$} & \multicolumn{2}{|c|}{ Number } & \multirow[t]{3}{*}{$\begin{array}{c}\mathrm{P} \\
\text { Valu } \\
\mathrm{e}\end{array}$} \\
\hline & & \multicolumn{2}{|c|}{ Exactly } & \multicolumn{2}{|c|}{$\begin{array}{c}\text { Inapprop } \\
\text { riate }\end{array}$} & & & \\
\hline & & $\overline{\mathrm{N}}$ & $\%$ & $\overline{\mathrm{N}}$ & $\%$ & $\mathrm{~N}$ & $\%$ & \\
\hline 1 & $\begin{array}{l}\text { Complicat } \\
\text { ion }\end{array}$ & 67 & 83.8 & 3 & 3.8 & 70 & 87.5 & \\
\hline \multirow[t]{3}{*}{2} & No & 6 & 7,5 & 4 & 5,0 & 10 & 12,5 & 0,000 \\
\hline & $\begin{array}{l}\text { Complicat } \\
\text { ions }\end{array}$ & & & & & & & \\
\hline & Total & 73 & 91.3 & 7 & 8.8 & 80 & 100 & \\
\hline
\end{tabular}

Source: Primary Data

\section{IV.DISCUSSION}

Early Detection Using Score Poedji Rochjati

The distribution of the risk of pregnancy to postpartum mother was on the average the category of high-risk pregnancy with a score of 6-10. Among the 80 postpartum samples, there were 9 of them who were categorized as low-risk pregnancies, very high-risk were 21 postpartum mothers. The high score of pregnant women during pregnancy due to their age, height, history of SC, infant position, and severe preeclampsia.

According to Simarmata (2010) maternal age ( $<19$ years and $\geq 35$ years), tend to have a labor complication of 0.96 times compared to mothers aged 20-34 during labor. Mothers with a height of $145 \mathrm{~cm}$ or less reflect the size of the pelvis, which is associated with dystocia, this suggests an increased risk for complications in labor. According to Rusleena cesarean section 
number because CPD (Cephalopelvic Disproportion) is $8.1 \%$ of all deliveries, besides women who have height $\leq 145 \mathrm{~cm}$ are at risk 2, 4 times having a cesarean section due to CPD than women who have height $\geq$ $145 \mathrm{~cm}$.

Mothers with a history of the cesarean section must have scar tissue. Scar tissue is contraindicated for delivery because of uterine rupture, placenta previa, preeclampsia and preterm delivery (less than 37 weeks). So it is likely to experience birth cesarean section again in the next delivery. In addition to the history of SC, according to Eka Jatu Wulandari [4] whose mothers with preeclampsia had 3.664 times greater risk of extraction vacuum action than mothers who did not preeclampsia.

\section{CONCLUSION}

The high score of the mother to make mothers at the time of delivery process complicated one of them is partus jams caused due to a mismatch between the head of the fetus and pelvis mother (CPD). Mother pelvic images can be seen from a mother's height that is less than normal which is likely to have a narrow pelvic capacity. According to Gulardi and Basalamah, as much as $19.5 \%$ $-27.3 \%$ is a delivery with cesareans because of complications Cephalopelvic Disproportion / CPD.

In addition, the low score of the mother during pregnancy allows the mother also experienced complications of labor such as old partus that the process of childbirth lasted more than 24 hours in primi and more than 18 hours on the multi caused by the mother experienced KPD. According to research Pamingki Ritno [5] mothers who experience premature rupture of membrane at risk for experiencing the incidence of old partus 4,376 times compared with mothers who did not experience premature rupture of membranes. This illustrates that postpartum women who have a score poedji rochjati 2 not necessarily did not experience complications of labor, because there are other things that can not be detected at the time of pregnancy by using card score poedji rochjati but at the time of birth experience complications that is KPD.

Precision prediction score poedji rochjati against complications of labor

Postpartum women belonging to the high-risk pregnancy category, and very highrisk pregnancies experience complications of 67 postpartum women (96\%) whereas postpartum women belonging to low-risk but precise pregnancy did not experience birth complications as much as 6 people of puerperal women $(\mathrm{n}=8.2 \%)$. This study illustrates that postpartum women who fall into high and very high-risk pregnancies will be more at risk of complications at the time of delivery so that for the process of childbirth required action by doctors in health facilities such as hospitals. According to research Yuli Kusumawati pregnant women who are categorized as high-risk pregnancy have risk equal to 3.46 times experience of birth with 
action from a mother with low-risk pregnancy condition $(\mathrm{OR}=3,46,95 \% \mathrm{Cl}: 1,62-7,39)$, so to maternal delivery is performed in a hospital with a referral system in the womb. The results of the study have shown that postpartum women categorized as high and very high-risk pregnancies are 14 times more likely to experience labor complications than postpartum women who are categorized as low-risk pregnancies during pregnancy.

\section{REFERENCES}

[1]. World Health Organization (WHO). 2014. WHO, UNICEF, UNFPA, the world Bank. Trends in maternal mortality: 1990 to 2013. Geneva: World Health Organization.

[2]. Rochjati P. 2011. Antenatal Screening Pregnancy Moment, Risk Factor Detection Controller Early Risk HighRisk Pregnancy, Surabaya: Airlangga University Press.

[3]. Training of Dr. H. Moch. Ansari Saleh, (2017). AKI Report, IMR, Number of Delivery and Complications of Birth at RSUD Dr. H. Moch. Ansari Saleh Year 2013-2016.

[4]. Riski A, et al. 2014. Risk factors that affect the occurrence of complications at the time of delivery in the city of Malang [Internet]. [downloads 2016 December 20]; 22-27. Available at: http://jurnal.stikeskendedes.ac.id/index. php/maternity/article/view/4
[5]. Ambarwati MR, et al. 2011. Description of factors causing high-risk pregnant women [Internet]. [downloads 2016 December 20]; 2: 1-9. Available at: http://static.schoolrack.com/files/100398 /423669/volume2_nomorkhususHKN.pdf\#page $=5$

[6]. Arikunto, S. 2010. Research Procedures A Practice Approach. Jakarta: Rineka Cipta.

[7]. Cunningham, G F. 2010. Obstetrics Williams Issue 21. Jakarta: EGC.

[8]. Firaya TN, et al. 2013. Midwife attitudes about 14T examination with early detection of high-risk poedji eochjati score card in the working area of Puskesmas Kademangan Blitar Regency 2012 [Internet]. [downloads 2016 December 20]; 1 (3): 1-5

[9]. Irmayanti., 2011. Relationship Characteristics of Pregnant Women and Pregnancy Examination with Complications of Labor in RSUD Dr. Pirngadi Medan. Field

[10]. Ministry of Health RI. 2015. Decree of the Minister of Health of the Republic of Indonesia No. HK.02.02 / MENKES / $52 / 2015$ on the Ministry of Health's Strategic Plan 2015-2019. [Internet]. Jakarta

[11]. Manuaba, I B G, et al. 2009. Understanding Women's Reproductive Health. Jakarta: EGC. 
[12]. 2010. Midwifery Science, Gynecology and Family Planning for Education of Midwife Edition 2. Jakarta: EGC

[13]. Mochtar, R. 2009. Synopsis Obstetrics vol. 3. Jakarta: EGC

[14]. 2011. Synopsis Obstetrics. Jakarta: EGC

[15]. Notoatmodjo, S. 2010. Health Research Methodology. Jakarta: Rineka Cipta

[16]. 2012. Health Research Methodology. Jakarta: Rineka Cipta.

[17]. Oxorn, H. 2010. Physiology and Pathology of Labor. Jakarta: Essentia Medica Foundation

[18]. Prawirohardjo, S. 2010. Obstetrics Science. Edition 4. Jakarta: Foundation Bina Pustaka Sarwono Prawirohardjo.

[19]. 2010. The science of Midwifery. Jakarta: Yayasan Bina Pustaka Sarwono Prawirohardjo.

[20]. Saifuddin, A B. 2008. National Reference Book of Maternal and Neonatal Health Services. Jakarta: Yayasan Pustaka Sarwono Prawirohardjo.

[21]. Simarmata, O S, et al. 2010. Determinant Genesis of Complications of Labor In Indonesia: Anlisa Secondary Data Basic Health Research 2010 [Internet]. [downloaded 2017 March 24]. Available at: http: /journal\%20bhs.inggris/ipi324886.pdf
[22]. Sugiyono.2010. Qualitative Quantitative Research Methods and R \& D, Alfabeta, Bandung.

[23]. Varney H, et al. 2008. Textbook of Midwifery Care Vol. 2 Issue 4. Jakarta: EGC Medical Book.

[24]. Wiknjosastro, H. 2009. Science midwifery.Jakarta: PT Bina Pustaka 